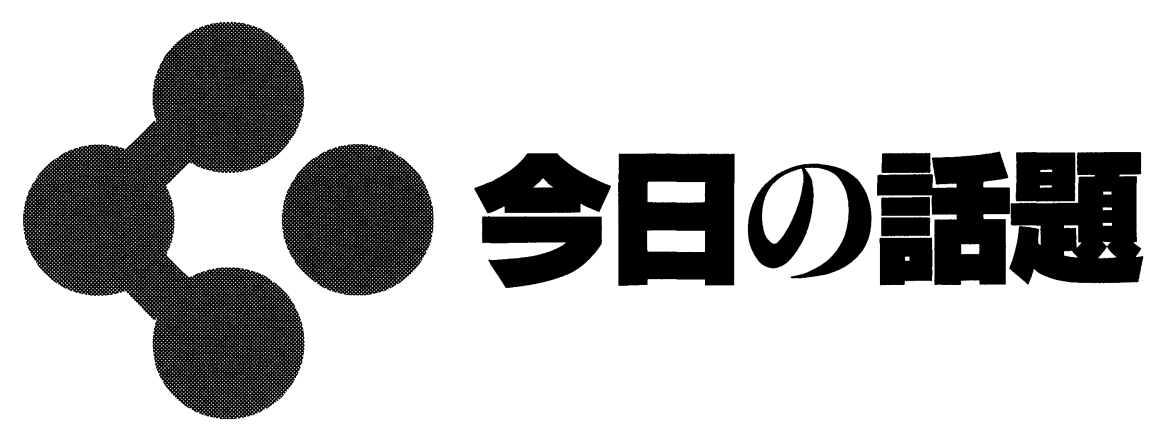

\title{
光合成能を向上させた植物の分子育種 ラン藻のカルビン回路構成酵素の導入によって光合成能と生育能が増強！
}

急速に進行しつつある地球規模での人口増加や環境悪 化は, 今世紀の農作物の安定供給と食糧需要に大きな影 響を及ぼす. 2050 年には世界の人口は約 93 億人に達す るとの推測に対し, 地球全体の耕地面積や穀物収穫量の 増加はなかなか見込めないのが現状である. 実際, 過度 の放牧, 森林伐採, 塩類集積などによる緑地の砂漠化が, 1 分当たり東京ドームのグランド 7 個分 $(500$ 万へクター ル以上/年)のスピードで進行している.また, 熱帯地域 の森林面積の減少は 1,230 万へクタール/年(日本の国土 面積の約 $1 / 3)$ の速度で進んでいる(1). さらに, 大気中の 高 $\mathrm{CO}_{2}$ 濃度に起因した地球温暖化により, 生態系への 影響, 異常気象など様々な問題も起こりつつある.この ような危機的状況を打破する解決策として, 植物バイオ サイエンスに望まれることは, 有用遺伝子導入によって 多くの環境ストレスに対して而性を示し, かつ生育能が 高く単位面積当たりの収穫量が多い, 新しい作物の作出 (分子育種)にあると思われる.

植物の物質生産能を向上させるには, (1)ソース器官 （光合成を活発に行なう器官. 主に葉）での糖の合成能 力, (2)ソース器官で合成された糖のシンク器官 (光合成 により合成した糖を貯蔵する器官. 主に塊茎, 穂など） への転流効率, (3)シンク器官での貯蔵能の強化, を考え なければならない.そしてこれまでに，これらの能力向 上を目指した形質転換植物の作出が数多く試みられてき た(図 1).

トウモロコシやサトウキビなどの $\mathrm{C}_{4}$ 植物が, $\mathrm{C}_{3}$ 植物 より効率のよい光合成機能をもつことは周知の事実であ
る.そこで, $\mathrm{C}_{4}$ 植物の $\mathrm{CO}_{2}$ 濃縮に関与する酵素遺伝子 を $\mathrm{C}_{3}$ 植物へ付与するために, トウモロコシ由来ホスホ エノールピルビン酸カルボキシラーゼの夕バコへの導入 が試みられた。 その結果, 高酸素濃度下での光合成活性 の阻害が抑制されたが, 表現型に変化は認められなかっ た ${ }^{(2)}$.また, ショ糖合成系の律速因子の一つと考えられ るショ糖リン酸合成酵素を導入したトマトは, 葉内のデ ンプン量に比べてショ糖量が増加し, 栄養成長期の地上 部の乾燥重量が地下部に比べて増加する傾向が認められ ている( ${ }^{(3)}$. デンプン合成の律速酵素である ADP グルコ ースピロホスホリラーゼ (AGPase) のアロステリック調 節を欠損させた大腸菌遺伝子を, 塊茎アミロプラスト (シンク器官でのデンプン合成の場)で発現させたバレイ ショは, 塊茎のデンプン量が増加したが, 特に植物体の 大きさに変化はなかった ${ }^{(4)}$. 以上のように, 糖代謝（生 産，分配や転流など）に関与する酵素遺伝子を過剩発現 した形質転換植物において, 顕著な収量の増大が認めら れた例は少ないのが現状である.

ところで, 光合成炭素還元系 (カルビン回路) の律速 因子を明らかにすることを目的に, 関連する酵素遺伝子 の発現を抑制した形質転換植物も多く作出されている. Rubisco（リブロース-1,5-ビスリン酸カルボキシラー ゼ/オキシゲナーゼ, $\mathrm{C}_{3}$ 植物における $\mathrm{CO}_{2}$ 固定経路の初 発酵素), $\mathrm{NADP}^{+}$-グリセルアルデヒド-3-リン酸デヒド ロゲナーゼ $\left(\mathrm{NADP}^{+}-\mathrm{GAPDH}\right)$, ホスホリブロキナーゼ (PRK)などをターゲットとした多くの形質転換体は，こ れら活性の減少に伴う光合成活性の低下があまりみられ 


\section{今日の話䧗 \&6}

なかった。一方，セドへプツロース-1,7-ビスホスファタ 一ゼ (SBPase) ${ }^{(5)}$ ，フルクトース-1,6-ビスホスファター ゼ (FBPase) $)^{(6)}$ ，トランスケトラーゼ，アルドラーゼを抑 制した形質転換植物は，活性の低下に伴い光合成活性に 著しい低下が認められた。さらに，高等植物葉緑体内で のカルビン回路において，1 分子のジヒドロキシアセト ンリン酸 (DHAP) を合成するのに必要とされる，それ ぞれの酵素活性の理論值と実際の細胞内の活性を比較し てみると, SBPase, FBPase 活性は他の酵素活性に比べ て低い值を示した。以上の結果から，カルビン回路の中 で，FBPase および SBPase は最も重要な律速因子であ ると考えられた。

一方，筆者らは，ラン藻のカルビン回路の調節系を検 討する過程で, 新規のフルクトース-1,6-/セドヘプッロ ース-1,7-ビスホスファターゼ (FBP/SBPase)を見いだ した ${ }^{(7)}$. 本酵素は，(1)ラン藻に広く分布する，(2)動植物 に存在する FBPase および SBPase とは一次構造がま
ったく異なる，(3)フルクトース 1,6-ビスリン酸とセド ヘプツロース 1,7-ビスリン酸の両方を加水分解するこ とができる，などの特性を有していた。そこで，高等植 物カルビン回路増強によるソース・シンク器官の糖代謝 への影響を検討するために，FBP/SBPase を葉緑体で 発現させた形質転換夕バコの作出を試みた。その結果, 光合成能および生育能が優れた形質転換植物を作り出す ことに成功した(8).

この形質転換夕バコは，大気条件下 $(360 \mathrm{ppm} \mathrm{CO}$ ) において光合成能が 1.24 倍に増加していた。また，野 生株よりも生育が早く, 最終的な背丈および乾燥重量は 1.5 倍に上昇し, 根, 菱, 葉なども著しく発達していた (図 2). 光合成最終産物であるへキソース，ショ糖，デン プンにも有意な増加が認められた。根における $\mathrm{g}$ 湿重量 当たりのデンプン量は同じであるが，形質転換体の根自 体が 3 倍に増加しているため，植物体当たりのデンプン 量は 3 倍に達した。また，形質転換体のカルビン回路代

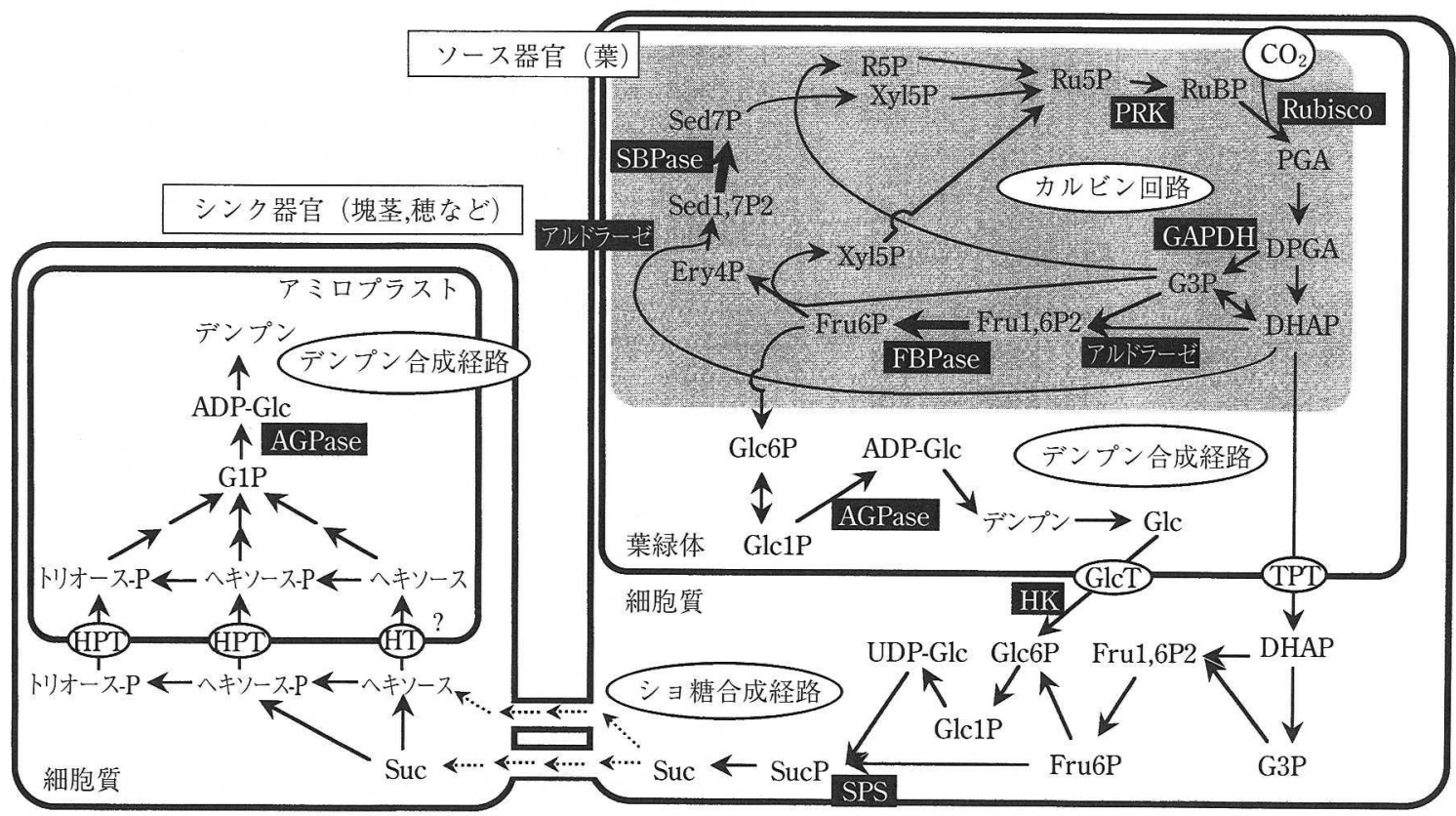

図 1 ロソース・シンク器官における光合成炭素代謝の模式図および収量增大のためのターゲット

太線はラン藻 FBP/SBPase 導入により強化された経路を示す.ADP-Glc：ADP-グルコース, AGPase：ADP-グルコースピロホスホリラ 一ゼ, DHAP：ジヒドロキシアセトンリン酸, DPGA：1,3-ジホスホグリセリン酸, Ery4P：エリスロース 4-リン酸, FBPase：フルクト ース-1,6-ビスホスファターゼ, Fru1,6P2：フルクトース 1,6-ビスリン酸, Fru6P：フルクトース 6-リン酸, G1P：グルコース 1-リン酸, $\mathrm{G} 3 \mathrm{P}$ : グリセルアルデヒド 3-リン酸, GAPDH：グリセルアルデヒド-3-リン酸デヒドロゲナーゼ, Glc：グルコース，Glc1P：グルコース 1-リン酸, Glc6P：グルコース 6-リン酸, GlcT：グルコーストランスポーター, HK：ヘキソキナーゼ, HPT：ヘキソースリン酸トランス ポーター, HT : ヘキソーストランスポーター, PGA : 3-ホスホグリセリン酸, PRK：ホスホリブロキナーゼ, R5P : リボース 5-リン酸, Ru5P：リブロース 5-リン酸, Rubisco：リブロース-1,5-ビスリン酸カルボキシラーゼ/オキシゲナーゼ, RuBP：リブロース 1,5-ビスリン 酸, SBPase：セドヘプツロース-1,7-ビスホスファターゼ, Sed1,7P2：セドヘプツロース 1,7-ビスリン酸, Sed7P：セドヘプッロース 7-リ ン酸, SPS：ショ糖リン酸合成酵素, Suc：ショ糖, SucP：ショ糖リン酸, TPT：トリオースリン酸トランスポーター, UDP-Glc：UDPグルコース, Xyl5P：キシルロース 5-リン酸 


\section{今日0)話题 \&o}

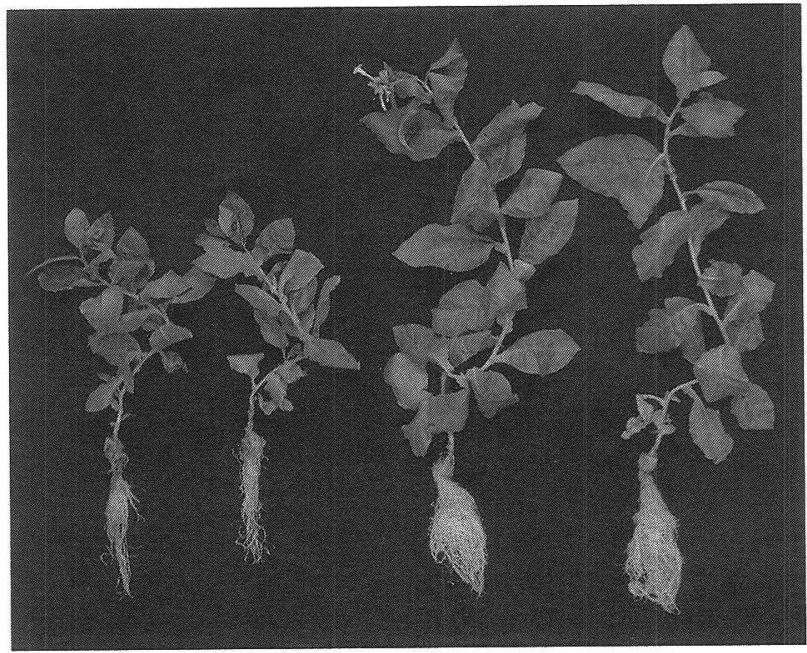

図 2 日光合成能を向上させた形質転換タパコ

播種後 18 週目の野生株 (左 2 つ) とラン藻 FBP/SBPase を導入し た形質転換体 (右 2 つ)。光強度 $400 \mu \mathrm{E} / \mathrm{m}^{2} / \mathrm{s}$, 大気 $\mathrm{CO}_{2}$ 濃度 (360 $\mathrm{ppm} \mathrm{CO}_{2}$ ), 明/暗期：12/12 時間の条件下で水耕栽培を行なった。 形質転換体は播種後 7 週目ぐらいから有意に大きくなり始め, 18 週後には野生株に比べて, 平均背丈および乾燥重量が 1.5 倍に増加 していた。形質転換体の光合成能 $\left(\mathrm{CO}_{2}\right.$ 固定能) は野生株の 1.24 倍 に増加していた。

謝中間体も有意に上昇していた。特に, RuBP(リブロー ス 1,5-ビスリン酸, $\mathrm{CO}_{2}$ とともに Rubisco の基質とな り，3 ホスホグリセリン酸に変換される）量は野生株の 約 1.8 倍となった。形質転換体では, FBPase および SBPase 以外のカルビン回路の構成酵素には, 有意な活 性上昇は認められなかった。しかし，この植物体では興 味あることに, Rubisco の全活性変化は認められなかっ たが，形質転換体の活性化率が野生株の 1.2 倍に上昇し ていた。現時点では光合成能が増加した詳細なメカニズ ムは不明であるが，筆者らは，形質転換体において増加 したRuBP き隹し Rubisco アクティベース (Rubisco の活性化を促進する酵素) の活性化により Rubisco の活 性化が起こったと考えている。 以上，RuBP 再生に関与 するFBPase および SBPase が, カルビン回路での炭素
の流れの調節，およびソース・シンク器官間の炭素分配 において，非常に重要な位置にあることが明らかになっ た。しかし現時点では，光合成活性の増加が，FBPase， SBPaseのいずれか，もしくは両方の酵素活性の上昇に 起因しているかは明らかではない。

ラン藻の FBP/SBPase をタバコ葉緑体で発現させる ことにより, 現在の大気条件下で光合成活性が上昇し, 植物体でデンプン, ショ糖の蓄積量が増大し, 生育が促 進して収量の増大につながったと考えられる。このよう に, 光合成炭素代謝に関連する酵素遺伝子を導入するこ とにより，格段に作物収量の増大が認められたのは初め てである。筆者らはすでに, 大腸菌カタラーゼ遺伝子を 導入することで，乾燥・強光に耐性を示す形質転換植物 の作出に成功している(9,10)。このような分子育種により 多収量が期待でき，複合的な環境ストレス条件下で成育 可能な形質転換植物 (穀類)の創成が, 大気中の $\mathrm{CO}_{2}$ 濃度 上昇による地球温暖化抑制や食糧危機の回避などに対し て有効な解決策の一つとなることを期待したい。

1）農林水産省：“平成 12 年度食料自給率レポート・食料需給表”。

2) M.S.B. Ku, S. Agarie, M. Nomura, H. Fukuyama, H. Tsuchida, K. Ono, S. Hirose, S. Toki, M. Miyao \& M. Matsuoka : Nature Biotechnol., 17, 76 (1999).

3) N. Galtier, C.H. Foyer, J. Huber, T.A. Voelker \& S.C. Huber: Plant Physiol., 101, 535 (1993).

4) D.M. Stark, K.P. Timmerman, G.F. Barry, J. Preiss \& G. M. Kishore : Science, 258, 287 (1992).

5) E.P. Harrison, N.M. Willingham, J.C. Lloyd \& C.A. Raines: Planta, 204, 27 (1998).

6) J. Ko $\beta$ mann, U. Sonnewald \& L. Willmitzer : Plant J., 6, 637 (1994).

7) M. Tamoi, T. Ishikawa, T. Takeda \& S. Shigeoka : Arch. Biochem. Biophys., 334, 27 (1996).

8) Y. Miyagawa, M. Tamoi \& S. Shigeoka : Nature Biotechnol., 19, 965 (2001).

9）重岡 成, 田茂井政宏, 宮川佳子: 蛋白質核酸䣲素, 44, 2246 (1999).

10) Y. Miyagawa, M. Tamoi \& S. Shigeoka: Plant Cell Physiol., 41, 311 (2000).

(田茂井政宏, 宮川佳子, 重岡 成, 近畿大学農学部)

\section{○|キトサンの三次元構造は亡゙こまでわかったか セルロースやキチンにはない第 2 の構造や, 酸イオンの水分子引き抜き作 用なビユニークな姿がみえてきた}

医用・医療材料, 化粧品, 食品添加物などへの適用で, 今, 最も話題性に富んでいる多糖類であるキトサン[ポ

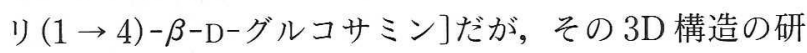

究は，同じく多糖類であるセルロース，デンプン，そし てキチンにも大きく遅れており，構造の詳細が明らかに なってきたのは 1990 年代中頃以降である(1 3). 中でも， 


\section{今日の話题 \&o}

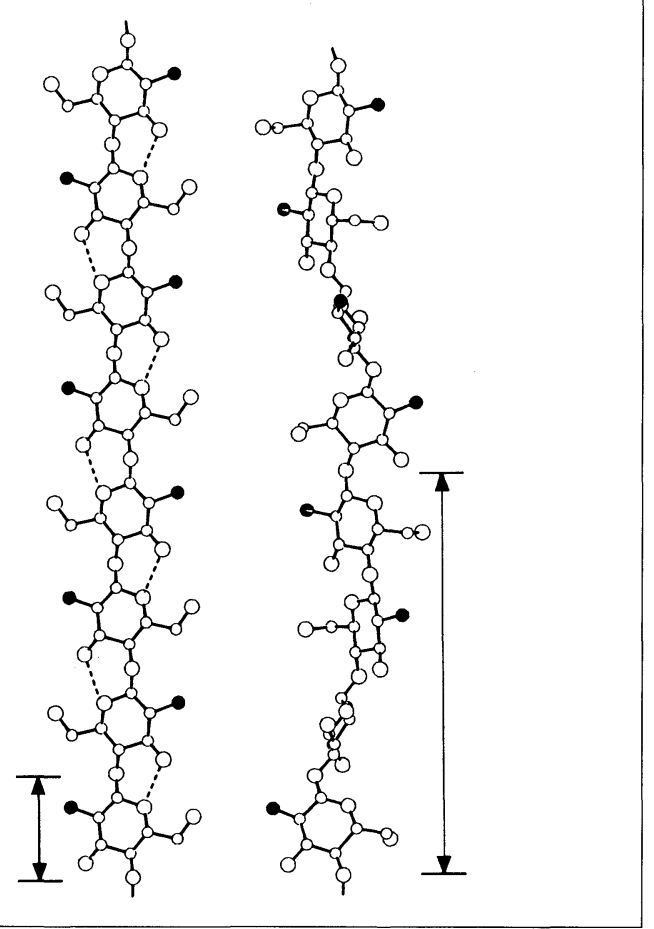

図 1 -キトサン分子鎖の $3 \mathrm{D}$ 構造

左：よく延びた 2 回らせん, 右：少し縮んだ 2 回らせん（タイプII 型). 大きい白丸は酸素, 小さい白丸は炭素, 黒丸は窒素, 水素は省 略, 破線は水素結合. 矢印は立体化学的繰り返し構造の基本単位 (asymmetric unit).

ロブスターの足の腱 (tendon) のキチンを脱アセチル化 して調製したキトサン試料から得たことから「Tendon」 型(4) と呼ばれる結晶の $\mathrm{X}$ 線繊維図形が得られたのは 1937 年 ${ }^{(5)}$ であった.しかし，その解析結果が公表された のは，実に 60 年後の 1997 年である(2).これは，構造解 析に必要な電算機の登場と高性能化を待たなければなら なかったことも原因であるが，何といっても，キトサン とその原料であるキチンの利用を目指した研究が始まっ たのが，事実上 1970 年代後半だったからである. 本稿で は，これまで明らかにされてきたキトサン 3 種の結晶に おけるキトサン分子の 3D 構造を紹介する.

Tendon 型は含水結晶であるが，たいていのキトサン 試料は結晶化度の差こそあれ，この結晶構造をもってい る.この結晶においてキトサン分子鎖は図 1 左に示すよ うに，モノマーであるグルコサミン残基を基本単位（こ れを非対称単位（asymmetric unit）と呼んでいる）と して，2 残基で立体化学的繰り返しを構成する，よく延 びた 2 回らせん (ジグザグ) 構造をとっている.この構 造は分子内水素結合 (図の破線) で安定化されているが,
キトサンと同じく $\beta-1,4-$ 結合からなる多糖類であるセ ルロースやキチンと共通した構造である. 図 $2^{(6)}-\mathrm{A}$ はこ の結晶の $a b$ 面の投影図，いわば断面図である，灰色で 覆ったキトサン鎖と他のキトサン鎖は互いに逆の方向を 向いており，結晶格子の $b$ 軸に沿って，互いに逆平行の 分子鎖が分子間水素結合（破線）を介してシートを作っ ている，そして，シート間は水分子を介して水素結合で 結びついている(2).

Tendon 型キトサン試料を水に浸して $200^{\circ} \mathrm{C}$ 前後で 熱処理（アニーリング）すると，無水結晶である「Annealed」型(4) となる.この結晶におけるキトサン分子鎖 の 3D 構造は, 先の Tendon 型とほぼ同じくよく延びた 2 回らせん(図 1 左)であるが，分子鎖間は図 2-B に示す ものとなる(3). つまり，熱処理によって水分子が排出さ れるのみならず, 分子鎖が移動して, 互いに平行なキト サン分子鎖どうしが水素結合を介してシートを作成し， 隣接シート間は互いに逆平行となる，なお，この結晶変 換は不可逆過程である。

以上のように, 含水・無水両結晶において, キトサン 分子鎖の $3 \mathrm{D}$ 構造はよく延びた 2 回らせんであるが，他 の構造もとりうることがキトサンの酸塩で見つかった。 キトサンはそのモノマーが遊離のアミノ基 $\left(-\mathrm{NH}_{2}\right)$ をも ったグルコサミンであるので，陽イオン性高分子化合物 である、したがって，酸と反応して塩となる、これまで に，キトサン塩の結晶は，塩におけるキトサン分子鎖の $3 \mathrm{D}$ 構造によって 2 種類に分類されることがわかってい る ${ }^{(7)}$. その中でタイプII と名づけられた塩では, 図 1 右 に示すような少し縮んだ構造となる(8). 図 1 左のよく延 びた 2 回らせん構造では，1つのグルコサミン残基が非 対称単位であるのに対して, 縮んだタイプII型ではグル コサミン残基 4 つ(つまりテトラマー) が非対称単位で,

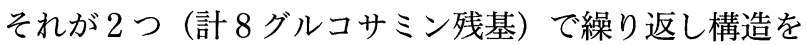
構成する 2 回らせん構造をとっている. タイプII塩は含 水型であるが，酸の種類にかかわらず，すべてほほ同じ 纎維図形を示すという特異的な特徵をもっている ${ }^{(7,9)}$.こ の事実は，結晶において酸イオンが定位置にないことを 示しており，このことはとりもなおさず，タイプII塩の 纎維図形が，塩におけるキトサン分子鎖そのものの $3 \mathrm{D}$ 構造を反映していることを示している.つまり，キトサ ンには，セルロース（誘導体を除く）やキチンにはみら れない, 第 2 の $3 \mathrm{D}$ 構造が存在する. 図 2-C は夕イプII 塩の $a b$ 面投影図である. 図で酸イオンを描いていない 


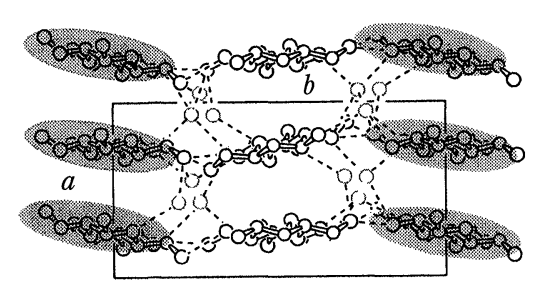

A (Tendon型)
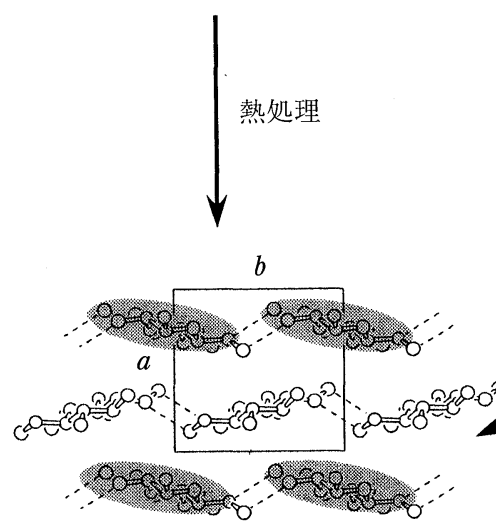

B (Annealed型)

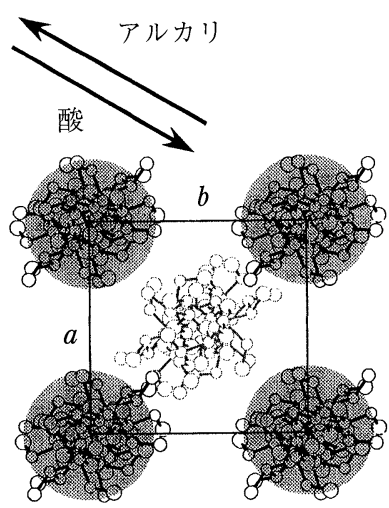

C（タイプII型）

\section{放置または}

イソプロピルアルコール

水溶液に浸す

\section{図 2 ロキトサン結晶の転移}

灰色で覆ったキトサンと他のキトサンとは分子鎖の向きが逆である. A の薄めの白丸は水分子の酸素原子, 破線は水素結合.

のは，その存在が X 線図形に反映されていないため, 結 晶内での位置が定まらないからである.

また，タイプII塩は「酸イオンによる自発的水分子引 き抜き作用」と呼ばれる, 今一つの大変奇妙な性質をも っている(9,10).酢酸などのモノカルボン酸とキトサンの 塩はタイプII塩の瀻維図形を示すが, 試料を一定期間保 存すると, キトサンの無水型結晶である Annealed 型の 繊維図形を示した。つまり，保存中に酸イオンが自発的 に水分子を伴って抜け出し, その結果, 無水型結晶が生 成したのである.このことは, 試料の密度や赤外線吸収 スペクトル測定によっても確認された ${ }^{(10)}$.この結晶構造 の変換も, 図 2 に示すように不可逆過程である. なお, 調製直後のタイプII塩をアルカリ溶液に浸すと, キトサ ンの含水型結晶に戻る。

「水分子引き抜き作用」は，キトサンーモノカルボン酸 塩では保存中に, 特に相対湿度が高いほど短い時間で起 こったが，他のすべてのタイプII塩でもイソプロピルア ルコール水溶液に浸すことによって起こる。なぜ出発物 質である Tendon に戻らずに，無水型の Annealed に 行ってしまうのかについてはわかっていないが，一つ考
えられることがある.タイプII塩での少し縮んだ 2 回ら せん(図 1 右)では, よく延びた 2 回らせん構造(図 1 左) に存在する強い分子内水素結合はほとんどみられないの で，この構造自体は不安定で，酸である対イオンの存在 によって安定化されている.ところが, 空気中の水蒸気 あるいはイソプロピルアルコール水溶液の水への酸イオ ンの解離が起こり, タイプII型が維持できなくなり, よ り安定な 2 回らせん構造のキトサン分子になる.そのと き, 元の含水結晶には戻らずに, 結晶全体としてょり安 定な無水型になると考えられる。

キトサンは，自然界でセルロース（年間 $10^{11}$ トン）に 次いで大量に生産されている, キチン $\left(10^{9}\right.$ トン $)$ から生 産されるバイオマスである。この多糖が化学構造が類似 のセルロースやキチンにはない 3D 構造をとれるのは, 構成単糖に一級アミノ基が存在するからである. また， 酸塩が示すユニークな挙動など，キトサンならではの特 性が見つかってきている，これらの性質は，DDS(drug delivery system）のキャリアーをはじめとする医薬・医 用材料, ひいてはナノ材料としての利用など, キトサン の高付加価值化に貢献することが期待される. 
1) T. Yui, K. Imada, K. Okuyama, Y. Obata, K. Suzuki \& K. Ogawa: Macromolecules, 27, 7601 (1994).

2) K. Okuyama, K. Noguchi, T. Miyazawa, T. Yui \& K. Ogawa : Macromolecules, 30, 5849 (1997).

3) K. Okuyama, K. Noguchi, Y. Hanafusa, K. Osawa \& K. Ogawa: Int. J. Biol. Macromol., 26, 285 (1999).

4) K. Ogawa, S. Hirano, T. Miyanishi, T. Yui \& T. Watanabe: Macromolecules, 17, 973 (1984).

5) G.L. Clark \& A.F. Smith : J. Phys. Chem., 40, 863 (1937).

6) K. Okuyama, K. Noguchi, M. Kanenari, T. Egawa, K.
Osawa \& K. Ogawa: Carbohydr. Polym., 41, 237 (2000).

7) K. Ogawa \& S. Inukai : Carbohydr. Res., 160, 425 (1987).

8) K. Okuyama, K. Osawa, Y. Hanafusa, K. Noguchi \& K. Ogawa: J. Carbohydr. Chem., 19, 789 (2000).

9) J. Kawada, T. Yui, K. Okuyama \& K. Ogawa : Biosci. Biothechnol. Biochem., 65, 2542 (2001).

10) A. Yamamoto, J. Kawada, T. Yui \& K. Ogawa : Biosci. Biothechnol. Biochem., 61, 1230 (1997).

(小川宏蔵, 大阪府立大学先端科学研究所)

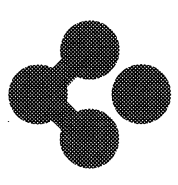

\section{核内イノシ} mRNA プロセシングやクロマチン 核の機能に関わることが明らかに

真核細胞の核内では, シグナル伝達物質として知ら れる phosphatidylinositol-4,5-bisphosphate (PtdIns $\left.(4,5) P_{2}\right)$ が細胞膜に存在するのとは別の様式で存在し ている可能性がある. 界面活性剤で核膜を除去した核 内にも, 核全体の約 $40 \%$ の PtdIns $(4,5) P_{2}$ が存在する という。つまり，核の膜構造以外 (核質内) にも PtdIns $(4,5) P_{2}$ が存在する. さらに, $\operatorname{PtdIns}(4,5) P_{2}$ に対する プローブとして最近よく用いられる GFP (green fluorescent protein) 融合 $\mathrm{PH}$ ドメイン（PH ドメインは $\operatorname{PtdIns}(4,5) P_{2}$ に結合する)や，抗 $\operatorname{PtdIns}(4,5) P_{2}$ 抗体 を用いて細胞を観察すると, 核膜には, 細胞膜における ような均一で著明な $\operatorname{PtdIns}(4,5) P_{2}$ の局在は見られず, むしろ核質や核内の特定構造（「核スペックル」と呼ばれ る構造や核小体)への集積が見られることが多い.また， 細胞外から脂肪酸部位を螢光標識した $\operatorname{PtdIns}(4,5) P_{2}$ を導入すると, 細胞質とともに核内の顆粒様構造に螢光 がみられる(1).これらの $\operatorname{PtdIns}(4,5) P_{2}$ がどのような状 態で存在しているかについての知見は, 現在のところま だ限られているが, 最近注目されるのは, mRNA プロ セシングと DNA 複製, あるいは転写制御を伴うクロマ チンリモデリングとの関係である.

プレ mRNA のプロセシング装置が存在するとされる 核スペックル（あるいはインタークロマチン顆粒集合体 (ICG)）は，構造的には核膜と連結しておらず，また核 質と膜構造で隔てられているわけでもない.しかし，こ こには $\operatorname{PtdIns}(4,5) P_{2}$ とともに，その合成に必要な 2 種類の PtdIns 5-キナーゼ（PtdIns (4) $P$ を主な基質と するタイプI と, $\operatorname{PtdIns}(3) P$ を主な基質とするタイプ II）が存在する(2).また，これらはsnRNPs（small nuclear ribonucleoprotein particles）と共局在する.
最近, PtdIns $(4,5) P_{2}$ が，転写装置を構成する RNA ポ リメラーゼ II やスプライシング因子 SC-35 のようなプ レ mRNA のプロセシング装置に含まれるタンパク質 と, 核内の限られた領域で共局在し, 細胞周期の各相で その存在状態が著明に変化することが報告された ${ }^{(3)}$. 彼 らは, PtdIns $(4,5) P_{2}$ に特異的なモノクローナル抗体を 利用した免疫螢光法と免疫電顕法とにより，核内の界面 活性剤で可溶化されない $\operatorname{PtdIns}(4,5) P_{2}$ は, ICG/核ス ペックルと思われる電子密度の濃い核内構造の中に見い だされることを確認した。この局在は, DNase には抵抗 性を示すが, RNase の処理により消失した.さらに，こ の局在は細胞分裂の間に顕著に変化した。すなわち，核 膜の消失に伴い, $\operatorname{PtdIns}(4,5) P_{2}$ は細胞質中に凝縮さ れ, 染色体が娘細胞に分配されるまでの間, DNA の動き とは別にそこにとどまった。ささらに，HeLa 細胞核抽出 物に対して抗 $\operatorname{PtdIns}(4,5) P_{2}$ 抗体による免疫沈降を行 なうと, 核抽出物に存在するスプライシング活性が除か れるが, PtdIns $(4,5) P_{2}$ を再添加してもその活性は回復 しなかった.このことから, in vitroでのプレ mRNA スプライシングには, PtdIns $(4,5) P_{2}$ が必須であるが, 抗体によって除かれるそれ以外の何らかの成分も必要で あることも示された。すでに, $\operatorname{PtdIns}(4,5) P_{2}$ がヒスト ン H1 に結合することにより，ヒストン H1の RNA ポ リメラーゼ II 活性抑制効果を解除することが報告されて いるが，核内 $\operatorname{PtdIns}(4,5) P_{2}$ は， mRNA の成熟過程に も重要な役割を担うことが示唆された。

核内での PtdIns $(4,5) P_{2}$ のもう一つの役割としては, DNA 複製あるいは転写調節に関連するクロマチンリモ デリングの制御が考えられる，真核細胞の DNA は，ク ロマチン構造の中にパッケージされることにより転写 


\section{今日の話题 \&。}

活性化を免れている。この抑制機構を解除する装置の 一つは，ヒストンの $\mathrm{N}$ 末端のリジンをアセチル化するヒ ストンアセチルトランスフェラーゼであるが，もう一つ は，ATPase ヘリカーゼ Swi2 をコアタンパク質とする 酵母の Swi/Snf 複合体に相当する ATP 依存的タンパ ク質複合体である。Swi2へリカーゼスーパーファミリ 一に属する動物細胞ホモログは，ショウジョウバエ Brahma 遺伝子産物と関係のある $\mathrm{Brg} 1$ と $\mathrm{hBrm}$ であ り，これらは他の 10 個のタンパク質とともに 2 メガ ドルトンの大きさをもつ BAF（BRG-または $\underline{B}$ rm-associated factor) 複合体を形成する。BA クロマチンリ モデリング複合体は，PtdIns $(4,5) P_{2}$ に依存してクロマ チンに結合し，クロマチンリモデリングの制御に重要な 役割を担うことが報告されている(4).

BAF や関連するSwi/Snf 様複合体のほとんどには, これまでにアクチン $(\gamma$ あるいは $\beta$ タイプ $)$, あるいはア クチン関連タンパク質 (Arp) が見つかっているが，最近 Rando らは, $\mathrm{BAF}$ 複合体が PtdIns $(4,5) P_{2}$ に依存して アクチン線維に結合することを明らかにした(5). HeLa 細胞から精製した BAF 複合体は，in vitro で PtdIns $(4,5) P_{2}$ を含む脂質べジクルや脂質・界面活性剤混合ミ セルと結合する。それと同時に，アクチン線維の末端に 結合し，そこで線維の分岐点を形成することが， $\left[{ }^{3} \mathrm{H}\right]$ $\operatorname{PtdIns}(4,5) P_{2}$ を組み込んだべジクルとの沈降実験，レ ーザー光散乱法による結合物の解析や電子顕微鏡による 観察により明らかになった。しかし，Brg1，アクチン， BAF53（Arp3 様タンパク質）の 3 つの構成成分を欠く
SW13 細胞から精製した BAF 複合体では，アクチンと の結合はもとょり, PtdIns $(4,5) P_{2}$ との結合もみられな かった。完全な BAF 複合体 (HeLa 細胞由来) は, PtdIns $(4,5) P_{2}$ の存在下でアクチン線維を安定化することがで きたが，不完全な複合体 (SW13 細胞由来)では PtdIns $(4,5) P_{2}$ がアクチン線維を安定化することはできなかっ た。後者で欠失している構成成分のうち，このPtdIns $(4,5) P_{2}$ 感受性に最も寄与していると考えられるのは, ATPase ヘリカーゼである Brg1(1647アミノ酸残基)で ある。DNA 依存的 ATPase 部分を含む C 未端約半分 にアクチンが結合し，1402 残基から 1418 残基に存在す る酸性アミノ酸と塩基性アミノ酸に富む領域にPtdIns $(4,5) P_{2}$ が結合することを示すデータが得られている (図 1)。BAF 複合体は，2つのアクチン様サブユニット をもつこと，in vitroでアクチン線維の分岐を形成しう ることから $\operatorname{Arp} 2 / 3$ 複合体に似ているといえる。細胞質 に存在するアクチン線維と同様の構造が，核内にも存在 するかどうかという点は従来から議論の的であるが， $\beta$ アクチンは核内外を行き来し，少なくとも一過的に核内 にとどまるらしい。さらに，in vivoで $\beta$ アクチンが $\mathrm{BAF}$ 複合体とクロスリンクできるという報告もある。 $\mathrm{BAF}$ 複合体は核マトリックスタンパク質と相互作用す ることも知られているので, 以上の結果は, $\operatorname{PtdIns}(4,5)$ $P_{2}$ 自身が，あるいはそれと結合したり修飾したりする 因子が，クロマチンリモデリング複合体の核マトリック ス局在シグナルとして働きうること示している。また， クロマチンの高次構造の維持と再編成にはタンパク質の
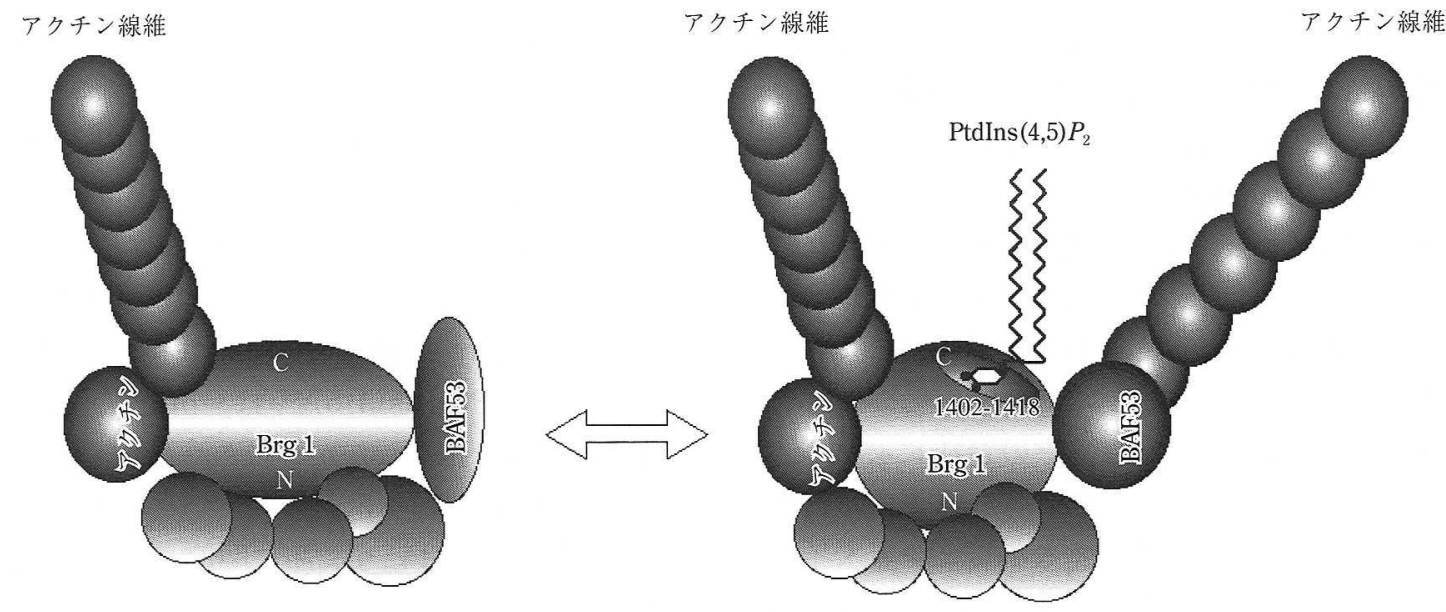

図 1 日 BAF クロマチンリモデリング複合体のアクチン線維に対する $\operatorname{PtdIns}(4,5) P_{2}$ 非依存的および依存的結合のモデル 
構造変化よりももっと大きな次元での力学的安定化の制 御が必要であるので, アクチン線維分岐を BAF 複合体 が安定化することは, クロマチンリモデリングにおける 力の発生を考察する際に有力なモデルを与える.

一方で, 核内 $\operatorname{PtdIns}(4,5) P_{2}$ は, 細胞膜におけるその 役割同様，ジアシルグリセロール $(\mathrm{DG})$ や Ins $(1,4,5) P_{3}$ という二次メッセンジャーの前駆体にもなっていると考 えられる. 核内には, $\operatorname{PtdIns}(4,5) P_{2}$ を分解するホスホ リパーゼCやリン酸化する PtdIns 3-キナーゼなど 種々の酵素や, PKC(プロテインキナーゼ C) や DG キナ 一ゼをはじめとする分解産物をリガンドとする下流のシ グナルタンパク質も存在する．これらの多くは核膜を隔 てて細胞質との間を行き来しており, 核外移行シグナル (NES)や核移行シグナル (NLS)のバランスのもと, リン 酸化・脱リン酸化などのスイッチによってその出入りが 制御されていると考えられている( ${ }^{(6)}$. 現在, これらの夕
ンパク質の核内における局在や活性の制御機構, 細胞増 殖や分化における生理的意義が問われている。 それぞれ が, DNA 複製, 遺伝子発現やサイレンシング, クロマチ ンリモデリング, 細胞分裂, アポトーシス, 核の運動と 再形成, 細胞の極性の決定など, 細胞の運命を決定する 核の機能に密接に関与している可能性がある.

1) S. Ozaki, D.B. DeWald, J.C. Shope, J. Chen \& G.D. Prestwich : Proc. Natl. Acad. Sci. USA, 97, 11286 (2000).

2) I.V. Boronenkov, J.C. Loijens, M. Umeda \& R.A. Anderson: Mol. Biol. Cell, 9, 3547 (1998).

3) S.L. Osborne, C.L. Thomas, S. Gschmeissner \& G. Schiavo: J. Cell Sci., 114, 2501 (2001).

4) K. Zhao, W. Wang, O.J. Rando, Y. Xue, K. Swiderek, A. Kuo \& G.R. Crabtree: Cell, 95, 625 (1998).

5) O.J. Rando, K. Zhao, P. Janmey \& G.R. Crabtree : Proc. Natl. Acad. Sci. USA, 99, 2824 (2002).

6) R. Irvine: Science STKE, Sep. 5, RE1 (2000).

(八木澤 仁, 姫路工業大学大学院理学研究科)

\section{| 微生物由来の多様なロ-アミノ酸含有ペプチド加水分解 酵素 細菌の細胞壁合成や变換に関わるだけではないその存在意義は?}

地球上の生物の体を構成するアミノ酸は, 少数の例外

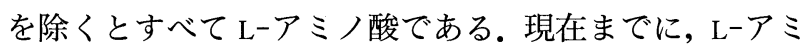
ノ酸からなるたんぱく質やペプチドに作用するプロテア 一ゼやペプチダーゼに関しては膨大な知見が蓄積されて いるが,これに比べて D-アミノ酸含有ぺプチドに作用 する酵素についての情報は, ごく少数に限られていた。

しかし，分析技術の向上に伴って，D-アミノ酸が従来考 えられていた以上に自然界に広く存在し, かつ重要な生 理的意義をもつことが明らかにされつつあり, また, Dアミノ酸が医薬, 農薬, 食品の合成原料としての利用が 期待されていることなどから, 研究も進み, $\mathrm{D}-ア ミ ノ$ 酸 含有ペプチドに特異的に作用する多様なペプチダーゼの 存在が判明しつつある(表 1).

$\mathrm{D}$-アミノ酸含有ペプチドを加水分解する酵素として

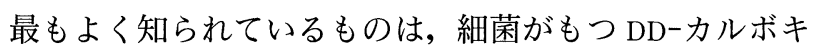
シペプチダーゼであろう. 本酵素は, ペプチドグリカン 合成中間体の UDP-ムラミルペンタペプチドのカルボ キシル末端- $(\mathrm{D}-\mathrm{Ala})_{2}$ から D-Ala を遊離させ, 新しいぺ プチドグリカン層を形成する反応を触媒するが, 条件に よっては C 末端-(D-Ala) ${ }_{2}$ の D-Ala と D-Ala の間を加 水分解する. また, 本酵素の活性中心 Ser 残基が, ペニ
シリンなどの $\beta$-ラクタム化合物のアミド結合のカルボ ニル炭素に求核付加をして寿命の長いアシル酵素複合体 を形成することにより，この酵素が触媒するトランスペ プチダーゼ活性が阻害され, ペプチドグリカンの生合成 が停止する.すなわち, 本酵素は $\beta$-ラク夕ム抗生物質の 標的分子であり，それと相同性を示す $\beta$-ラクタマーゼ 群とともに, ペニシリン認識酵素ファミリーを形成して いる.

一方, 筆者らは $\mathrm{D}-ア ミ ノ$ 酸およびその誘導体の酵素的 合成法の開発を目的として, 自然界より $\mathrm{D}$-立体特異的ぺ プチダーゼ生産菌の探索を行ない，世界に先駆けて以下 の D-特異的酵素を 3 種類発見した ${ }^{(1)}$. 土㙥細菌 Ochro-

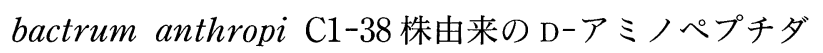
一ゼは, $\mathrm{D}-ア ミ ノ$ 酸 (特に立体的にかさの小さい D-Ala

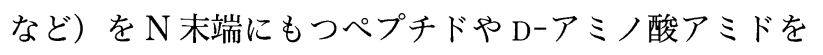
加水分解する(2). Bacillus cereus DF4-B 株が菌体外に 分泌するアルカリ D-ペプチダーゼは, D-Phe などのか

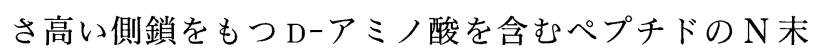
端から 2 番目のアミノ酸の $\mathrm{D}$-体を認識して, ジペプチド 単位で切り出す活性を有するエンドペプチダーゼであ る(3).また O. anthropi SV3 株由来のD-アミノ酸アミダ 


\section{今日の話漹 \&。}

表 1 微生物の $\mathrm{D}-ア ミ ノ$ 酸含有ペプチド加水分解酵素

\begin{tabular}{|c|c|c|c|}
\hline 酵素 & 由来 & 活性中心 & 立体選択性 \\
\hline DD-カルボキシペプチダーゼ & 細菌 & Ser & $-\mathrm{D}_{\uparrow}^{-} \mathrm{C}$ 末端 $\mathrm{D}$ \\
\hline $\mathrm{D}^{-ア ミ ノ ヘ ゚ フ ゚ チ タ ゙ ー セ ゙ （ D A P ） ~}$ & Ochrobactrum anthropi & Ser & $\mathrm{N}$ 末端 $\mathrm{D}-(\mathrm{D}$ または L $)$ \\
\hline アルカリ D-ペプチダーゼ（ADP） & Bacillus cereus & Ser & $\mathrm{N}$ 末端（D または $\mathrm{L}$ )- $\mathrm{D}_{\uparrow}^{-}(\mathrm{D}$ または $\mathrm{L})$ \\
\hline D-アミノ酸アミダーゼ（DaaA） & Ochrobactrum anthropi & Ser & $\mathrm{D}^{-}$アミノ酸アミド \\
\hline DD-ジペプチダーゼ（VanX） & Enterococcus & $\mathrm{Zn}^{2+}$ & （D または L $)_{\uparrow} \mathrm{D}$ (ジペプチド） \\
\hline VanX ホモログ（DdpX） & Escherichia coli & $\mathrm{Zn}^{2+}$ & (D または L $)_{\uparrow} \mathrm{D}$ (ジペプチド $)$ \\
\hline D-アミノペプチダーゼ（DppA） & Bacillus subtilis & $\mathrm{Zn}^{2+}$ & $\mathrm{N}$ 末端 $\mathrm{D}_{\uparrow} \mathrm{D}$ \\
\hline
\end{tabular}

个はぺプチド基質の切断部位を示す.

一ゼは，ペプチド基質にはまったく作用しないものの， Phe や Tyr などのかさ高い側鎖をもつアミノ酸のアミ ドを D-立体特異的に加水分解する ${ }^{(4)}$.

これら 3 種の酵素の有機合成への応用として, ラセミ 体アミノ酸アミドの光学分割による D-アミノ酸や $\mathrm{L}-ア$ ミノ酸アミドの合成，および $\mathrm{D}$ アアミノ酸メチルエステ ルからの D-アミノ酸オリゴペプチドの合成が可能であ る.さらに, PCR により D-アミノ酸アミダーゼ遺伝子 にランダム変異を導入したライブラリーから，耐熱性を 指標としてスクリーニングを行なった。その結果得られ た，耐熱性および触媒活性が向上した変異酵素を発現さ せた大腸菌菌体を用いて, $\mathrm{D}, \mathrm{L}-\mathrm{PheNH}_{2}$ の光学分割によ る効率的な D-Phe の合成が可能となっている.

これら 3 種の酵素の一次配列は，前述の $\mathrm{DD}$ ーカルボキ シペプチダーゼや $\beta$-ラクタマーゼと約 $30 \%$ の相同性を 有し，同じファミリーに属すると考えられる．最近決定 された D-アミノペプチダーゼの立体構造によると, 本酵 素は $\mathrm{A}, \mathrm{B}, \mathrm{C}$ のつのドメインからなり, 活性中心 Ser 残基を含むドメイン $\mathrm{A}$ の構造は $\mathrm{DD}$-カルボキシペプチ ダーゼと非常に類似していた. D-Ala $\mathrm{N}$ 末端にもつ ペプチドにアミノペプチダーゼ活性を示すという本酵素 特有の基質特異性は, 基質結合部位に突き出たドメイ ンCループの Asp 残基の負電荷によることが示され $た^{(5)}$.

ペニシリン認識酵素ファミリーに属さないD-立体 特異的ペプチダーゼとしては，バンコマイシン耐性 菌 Enterococcus faecium がもつ DD-ジペプチダーゼ, VanX が挙げられる. 抗生物質バンコマイシンは，グラ ム陽性菌の細胞壁ペプチドグリカンの生合成途中にその 末端-(D-Ala $)_{2}$ に結合して，糖転移およびペプチド転移 反応を阻害するのだが, VanX はバンコマイシン耐性に おいて重要な働きをしている。すなわち，細胞質内にお
いて V V AnX がペプチドグリカン合成原料の (D-Ala $)_{2}$ を 加水分解し，代わりに $\operatorname{van} X$ とオペロンを形成する vanHA 産物によって合成された D-Ala-D-lactate がぺ プチドグリカンに取り込まれることで, バンコマイシン によるペプチドグリカン生合成の阻害を回避する.また， バンコマイシンタイプの抗生物質を生産するStreptomyces toyocaensis にも vanHAX オペロンが存在し, 自 己が作る抗生物質に対する免疫として機能していると考 えられている。一方，グラム陰性菌ではその細胞壁の構 造のためにバンコマイシンが細胞内に侵入できず，バン コマイシンによる攻撃を受けないが, 驚くべきことに, グラム陰性菌である Escherichia coliにも, VanX と 27\%の相同性をもち，V anX と同様の基質特異性を示す 酵素 DdpX が存在する(6).では，バンコマイシン耐性で もバンコマイシン生産菌でもないE. coli 内で, DdpX はどのような役割を果たしているのであろうか.

最近, Cheggour らは, Bacillus subtilis の培養上清 から $(\mathrm{D}-\mathrm{Ala})_{2} ， \mathrm{D}-\mathrm{Ala}-(\mathrm{Gly})_{2}$ に作用する酵素，D-アミ ノペプチダーゼ (DppA) を単離している. 本酵素は活性 発現に $\mathrm{Zn}^{2+}$ を要求し, アミノ酸配列は既知の D-立体特 異的ペプチダーゼとは相同性をもたず，かつその立体構 造は，活性部位を分子内部に配置するようにサブユニッ 卜 10 個が集まって樽型構造を形成した，いわゆる活性 部位内在型プロテアーゼである(7).

これらの D-アミノ酸含有ペプチド加水分解酵素の生 理的意義を考えるとき, それぞれの遺伝子の周辺領域や 発現時期が重要となる. E. coli の $d d p X$ はジペプチド輸 送たんぱく質遺伝子とともに， $d d p X A B C D F$ オペロン を形成し, 生育定常期で発現する $\sigma^{\mathrm{s}}(\mathrm{RpoS})$ 依存性プロ モーターより転写される。また，B. subtilis の dppA も ジペプチド輸送たんぱく質オペロンとともに胞子形成初 期に発現する.すなわち，これらの D-立体特異的ぺプチ 


\section{今日の話题 \&6}

ダーゼは，細菌が栄養欠乏状態に置かれたとき，何らか の形でペプチドグリカンから遊離した (D-Ala) 2 を栄養 源として利用するために，ジペプチド輸送たんぱく質に よって細胞質内に再導入された $(\mathrm{D}-\mathrm{Ala})_{2}$ をD-Alaに分 解する役割を担うと考えられる，興味深いことに，筆者 らが発見した D-アミノ酸アミダーゼは，(D-Ala $)_{2}$ を分 解する活性をもたないにもかかわらず，その遺伝子はジ ペプチド輸送たんぱく質遺伝子とオペロンを形成してい ることが示され，類似の生理的役割を予想させる。

微生物酵素を用いた有用物質生産を目的として D-立 体選択的加水分解酵素のスクリーニングの結果見いださ れた酵素と，抗生物質耐性のメカニズムを解明する過程 で発見された酵素は，いずれも D-アミノ酸を含む短鎖 ペプチドを特異的に切断し，意外にもぺプチドグリカン の合成，代謝，あるいは変換に関与するという接点をも っていた，ただし，その構造や反応機構は互いにまった く異なるものであり，しかも L-アミノ酸の世界で働く
L-立体特異的ペプチダーゼともまったく異なっていた. 自然界からは, ペプチドグリカン以外にも多数の D-アミ ノ酸含有ペプチドが発見されていることから，それらに 作用する D-立体特異的な分解酵素系の存在が予想され， 今後の解明が期待される.

1) Y. Asano \& T.L. Lübbehüsen : J. Biosci. Bioeng., 89, 295 (2000).

2) Y. Asano, Y. Kato, A. Yamada \& K. Kondo : Biochemistry, 31, 2316 (1992).

3) Y. Asano, H. Ito, T. Dairi \& Y. Kato : J. Biol. Chem., 271, 30256 (1996).

4) H. Komeda \& Y. Asano: Eur. J. Biochem., 267, 2028 (2000).

5) C. Bompard-Gilles, H. Remaut, V. Villeret, T. Prangé, L. Fanuel, M. Delmarcelle, B. Joris, J.-M. Frère \& J.V. Beeumen : Structure, 8, 971 (2000).

6) I.A.D. Lessard \& C.T. Walsh : Proc. Natl. Acad. Sci. USA, 96, 11028 (1999).

7) H. Remaut, C. Bompard-Gilles, C. Goffin, J.-M. Frère \& J.V. Beeumen : Nature Struct. Biol., 8, 674 (2001).

(米田英伸, 浅野泰久, 富山県立大学工学部)

\section{|個体の大きさを決める機構 線虫を用いて，大きくなるメカニズムを探る}

ゾウの体重はマウスより約 10 万倍大きく，哺乳動物 全体では種間の体重の違いは最大約 1,000 万倍ある，高 等植物でも小さな草と大木では，同程度の重さや体積の 違いがあるだろう。体の大きさと相関して, 動物では代 謝速度, 運動速度, 成長期間, 寿命, 生態的地位など多 くの形質が変化する，このように，個体の大きさは生物 の種の特徵を示す重要な指標である.

多細胞生物の個体の大きさは，主としてそれを構成す る細胞の数と大きさによって決まる。哺乳動物において は，たとえばヒトの体重と細胞数はマウスの值のそれぞ れ約 3,000 倍であり, 細胞数の違いが大きさの主な決定 要因であるらしい(1). 個体の大きさは年齢や栄養などの 環境要因によっても変化するが，成熟個体の平均的大き さ，すなわちその細胞の数と大きさは，ほぼ遺伝子によ って決定されていると考えられる。しかし，具体的に， どのような遺伝子によって, どのような機構で, 種の平 均的大きさが決定されているのかはまったく不明であ る.つまり, 細胞数の種間の違いの遺伝的要因はまった く明らかになっていない. また，細胞の大きさも生物界 全体では多様であり, その遺伝的要因として最もはっき
りわかっているものは, 染色体の倍数性あるいはゲノム DNA の総量である，昆虫などでは, 100 万プロイドの染 色体をもつ巨大細胞も存在する(2). しかし, 倍数性を決 定する遺伝子も未知である.

筆者らは，このような個体の大きさを決定あるいは制 御する機構に興味をもち, 線虫を用いて数年前から研究 を行なってきており，ここではその現状を紹介する，世 界的にも, 数年前からいろいろな生物について, 個体の 大きさを決定する機構の研究が急に盛んになっており, 主として種内での大型化, 小型化の機構が研究されてい $ろ^{(1)}$.

線虫（線形動物）には 10 万以上の種があり，その一部 は動物または植物に寄生するが, 大部分は地中, 海底, 川底などで自由生活を送っている. 線虫の個体数は地球 上の多細胞動物の中で最も多く, $1 \mathrm{~m}^{2}$ 当たりの川底に 100 万以上が棲息すると推定されている( ${ }^{(3)}$. Caenorhabditis elegans は, 本来土壌中で自由生活をする小型の線 虫であるが, 1970 年頃から遺伝学, 分子生物学の研究材 料として使われるようになり, 現在世界中の多くの研究 室で活発に研究が行なわれている(4 6). C. elegansの大 


\section{今日の話量 \&゚}

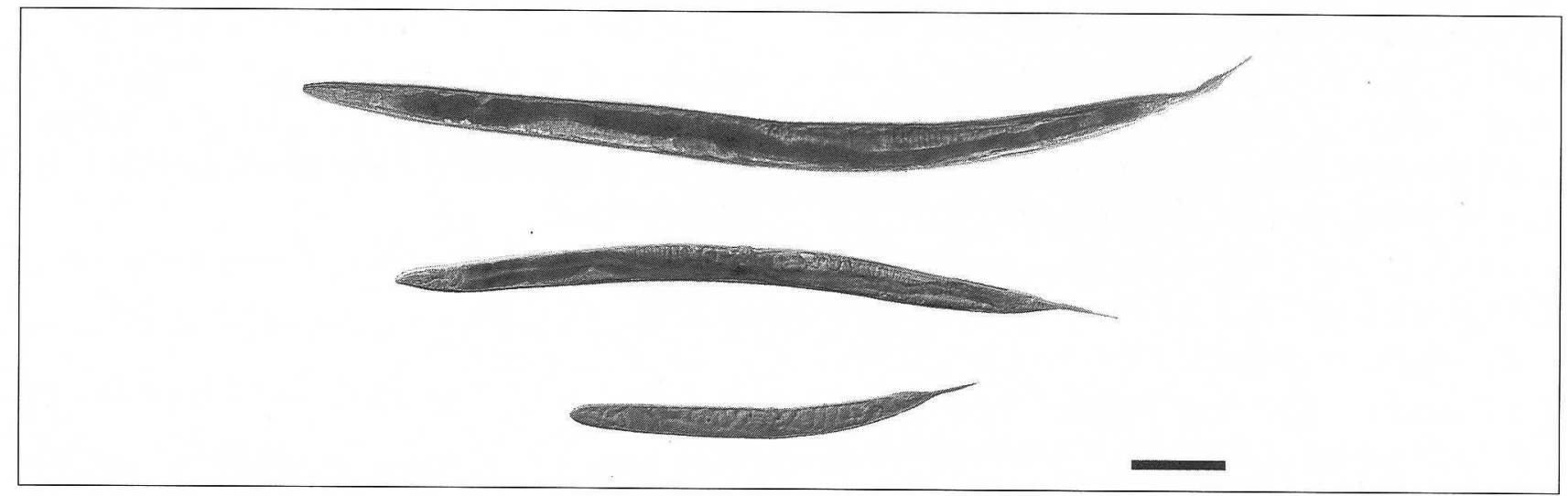

図 1 日線虫 $C$. elegans の野生型 (中央)，小型変異体 sma-6 (下) および大型変異体 egl-4 (ks61) (上) の個体

成虫になってから 4 日後の虫をアジ化ナトリウムで麻酔し，微分干渉顕微鏡で撮影した。スケールバーは $200 \mu \mathrm{m}$. 撮影：中野愛哉。

部分の個体は雌雄同体であり，その成虫体長は 1 1.5 $\mathrm{mm}$ ，実験室では寒天平板上で大腸菌を餌として飼育さ

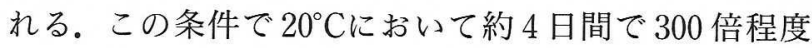
と，驚異的スピードで増殖する。全体細胞の系譜，全二 ユーロン間の結合が明らかにされ(4,5), 1998 年には全ゲ ノムの塩基配列もほほ決定された

筆者らは, C. elegans を用いて個体の研究を行なうた めの基礎として, その個体の体長, 直径, 体積を正確に そして迅速に測定する方法を開発した。そして，野生型 成虫の体積は約 $4 \mathrm{nl}$ であることを確かめた。C. elegans においては，筆者らが研究を始める以前から，体が小さ い変異株がいくつか知られていた(図 1)。そして，これ らの中でdaf(dauer-formation defective)-4, sma (small) - 2, 3, 4, 6 の原因遺伝子が, TGF- $\beta$ (transforming growth factor- $\beta$ ) 信号伝達経路の因子をコードする ことが比較的最近明らかにされた ${ }^{(8)}$. 筆者らは, 最近 $s m a-5$ の遺伝子のクローン化を行ない, それが哺乳動物 の MAP キナーゼ (mitogen activated protein kinase) の一つ BMK1/ERK5 (big MAP kinase 1/extracellular signal-regulated kinase 5) のホモログをコードするこ とを明らかにした(渡邊直春ら，未発表)。sma-5 变異株 は成虫の大きさが著しく小さい $(<1.5 \mathrm{nl})$ だけでなく， 一部の個体は幼虫致死を示し, また成長が非常に遅いな どの表現型を示す。哺乳動物において，BMK1/ERK5 は，EGF (epidermal growth factor) などの下流で細 胞の周期および増殖を調節することが知られており， $s m a-5$ も同様の働きにより,個体の大きさの制御にも関 与すると考えられる。いくつかの生物において, 共通的 にインシュリン様シグナル伝達系および $\mathrm{TGF}-\beta$ シグナ
ル伝達系が個体の大きさの制御に㗢くことが知られてい るが, sma-5 の研究により, 個体の大きさを制御する新 しい経路の存在が示唆された。

筆者らが C. elegans の個体の大きさについて研究し てきた最大のテーマは, 大型変異株の分離とその解析で ある。C. elegans, マウスやシロイヌナズナなど多くの 生物について, 小型の変異体は多数知られているが, 大 型の変異体の記載は見当たらない。しかし, 分子生物学 的に考えると，体や細胞の大きさは，これを大きくしよ うとする遺伝子 (因子) と, 逆に小さくしょうとする遺伝 子のバランスで決まっているに違いない．前者の機能喪 失や低下の変異体として小型のものが多数あるので， 後者の変異体として大型変異体が分離されるであろう と予想して実験を行なった。その結果，C. elegansで普 通に用いられる変異誘起剤 EMS (ethyl methanesulfonate)の処理により，成虫の体積が $50 \%$ 程度以上大き い独立の変異体を 20 種類あまり分離することができた。

このうち, 表現型の似た 4 株について詳しい解析を行 なった。これらは，形態，成虫になるまでの成長などは ほぼ正常であるが，その後より長く成長を続け，4 日後 に野生型個体の 2 倍近い大きさになる(図 1)。興味深い ことに, いずれも寿命が 5 割程度長く, 弱い産卵の異常 （遅れ）を示す。筆者らは，これらの原因遺伝子が共通で あり, egl(egg-laying defective)-4であることを見い だした。 $e g l-4$ 遺伝子は遺伝的には知られていたが，そ の原因遺伝子が同定されていなかったので，筆者らはク ローン化を行ない, cGMP依存性タンパク質リン酸化酵 素をコードすること，およびその発現パターンを明らか にした ${ }^{(9)}$ 。また，C. elegansの主要器官とその細胞の形 

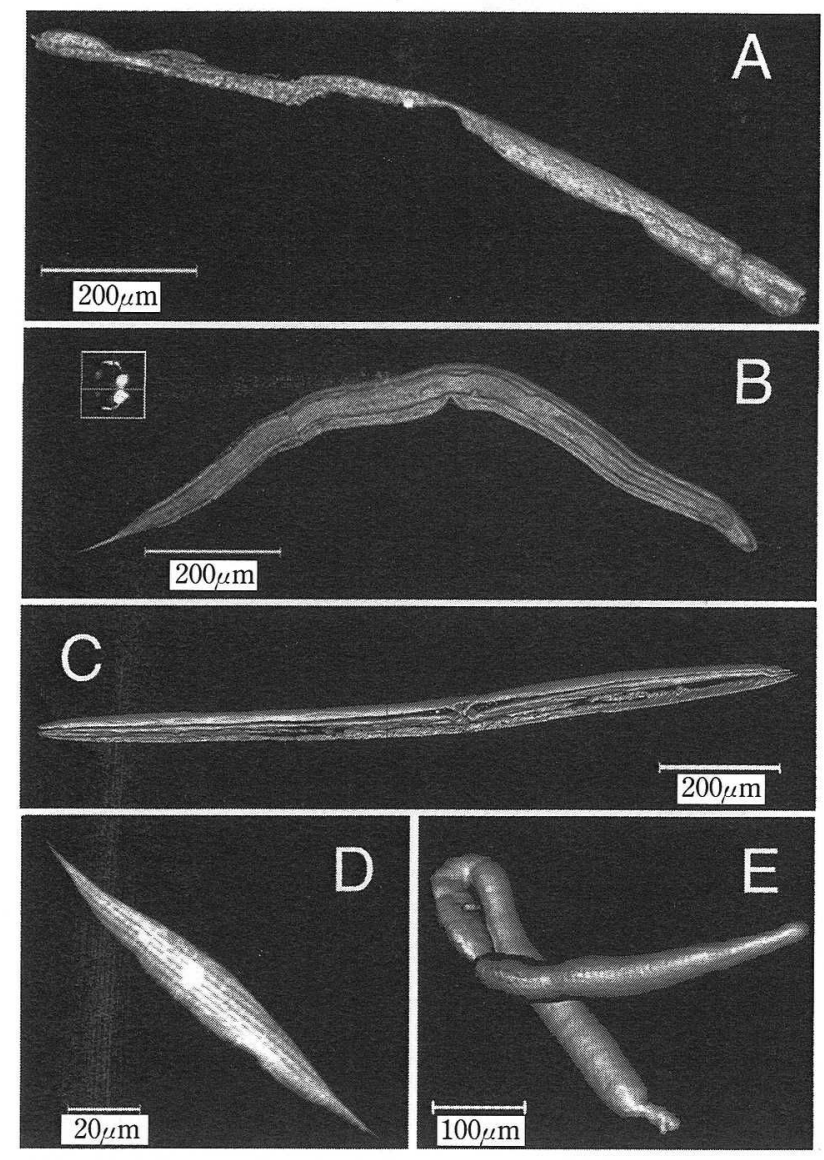

図 2 - C. elegans の野生型成虫の器官および細胞の形態

$\mathrm{A}$ : 腸, $\mathrm{B}$ : 下皮, $\mathrm{C}$ : 筋肉, $\mathrm{D}$ : 単一の体壁筋肉細胞, $\mathrm{E}$ : 生殖巣 (半分). $\mathrm{A} \sim \mathrm{D}$ については, それぞれの特定の器官のみで GFP (green fluorescent protein)融合遺伝子を発現するトランスジェ ニック系統の個体全体を, Eについては解剖により取り出した生殖 巣を FITC(fluorescein isothiocyanate)染色したものを用いて, 共焦点顕微鏡により $1 \mu \mathrm{m}$ 間隔で螢光の断層像を撮影し,これらに 基づいて構築した三次元像.これを用いてそれぞれの器官や細胞の 体積を測定することができる. B の左上の図は断面像を示す。

態，体積の解析方法を開発し(図 2)，これを用いて egl4 変異株に扔いて, 腸, 下皮, 筋肉全体および腸, 筋肉の 細胞が大型化していること，しかしその細胞数は変化し ていないことを明らかにした ${ }^{(9)} e g l-4$ 遺伝子による寿 命の制御は，インシュリン様シグナル伝達系と関連する こと，体の大きさの制御は TGF- $\beta$ 系の抑制によること も明らかにしている。

現在，これらのより詳細な機構の解析を行なうととも に, 他の大型変異体の解析も行なっている. また, 多重 変異や大型化遺伝子の導入を組み合わせて, C. elegans を野生型より 10 倍程度大きくすることを計画している。 以上の研究はいずれも, C. elegans 種内での大きさの変

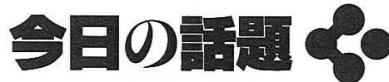

化，あるいは制御機構に関するものである。それ自身重 要な意義があり, 将来, 農作物, 家畜, ペット, 園芸植物 などの大型化・小型化，移植医療などに役立つ可能性が あると期待している。また,これらの機構は, 生物種間の 大きさの違いにも抢そらく関連するであろう。しかし， もっと直接に種間の大きさの原因を解析することも可能 かもしれない。その一つのやり方として，C. elegansよ り 100 万倍近く大きいが，分類や形態が比較的近い寄生 性線虫 (回虫) Ascaris 属の遺伝子を C. elegans へ導入 して，大型化遺伝子の同定に挑戦したい。

1) J. Conlon \& M. Raff : Cell, 96, 235 (1999).

2) V.Y. Brodsky \& I.V. Ury vaeva : "Genome Multiplication in Growth and Development", Cambridge University Press, 1985.

3）石橋信義：“線虫の生活”, 東京大学出版会, 1978.

4）小原雄治(編)：“線虫 1000 細胞のシンフォニー”, 共立出版, 1997.

5) W.B. Wood (ed.) : "The NEMATODE CAENORHABDITIS ELEGANS", Cold Spring Harbor Laboratory, 1988.

6) D.L. Riddle et al. (ed.) : “C. ELEGANS II”, Cold Spring Harbor Laboratory Press, (1997).

7) The C. elegans Sequencing Consortium: Science, 282, 2012 (1998).

8) G.I. Patterson \& R.W. Padgett: Trends Genet., 16, 27 (2000).

9) T. Hirose, Y. Nakano, Y. Nagamatsu, T. Misumi, H. Ohta \& Y. Ohshima : 投稿中

（大島靖美，九州大学大学院理学研究院） 